\title{
MENAJAMKAN PERSPEKTIF GENDER, MEMBERDAYAKAN PEREMPUAN DAN MENCAPAI SDGs (SUSTAINABLE DEVELOPMENT GOALS)
}

\author{
Laila Kholid Alfirdaus \\ alfirdaus_laila@yahoo.com; laila-alfirdaus@undip.ac.id \\ Jurusan Ilmu Pemerintahan, Departemen Politik dan Pemerintahan, Fakultas Ilmu \\ Sosial dan Ilmu Politik, Universitas Diponegoro, Semarang
}

\begin{abstract}
The issue of gender equality is still a concern of many parties. Continuing to improve, it seems that inequality and debate are still serious. Not only because of inequality and differences, the sharpening of gender perspectives and women's empowerment as a whole is crucial because basically every decision making of each development strategy has gender implications, without being released when using the present. This attribute underlines the gender argument in sharpening gender perspectives in development in order to achieve the Sustainable Development Goals (SDGs) targets. Sharpening perspectives can be done by strengthening women's empowerment strategies through more intensive and intensive stakeholder engagement. Integrating a gender perspective with development planning and implementation thus becomes an unavoidable necessity. SDG principles that contain universality (universality), published (comprehensive), and inclusive (nothing left behind) provide an atmosphere that is very conducive to supporting gender equality. SDGs are also equipped with implementation instructions so that it is easier for the government together with the community to achieve these development goals. The current challenge for SDHs lies in the willingness (willingness) of policy makers and development agents.
\end{abstract}

Keywords: gender perspective, women's empowerment, and participatory development

\begin{abstract}
Abstrak
Isu kesetaraan gender masih menjadi perhatian banyak pihak. Meski perbaikan mulai tampak, ketimpangan dan diskriminasi masih menjadi persoalan serius. Tidak hanya karena ketimpangan dan diskriminasi, penajaman perspektif gender dan pemberdayaan perempuan itu secara bersamaan menjadi krusial karena pada dasarnya setiap pengambilan keputusan serta setiap strategi pembangunan itu memiliki implikasi gender, tak terlepas pada situasi kekinian. Atikel ini menggarisbawahi argumentasi pentingnya penajaman perspektif gender di dalam pembangunan guna mencapai target Sustainable Development Goals (SDGs). Penajaman perspektif itu dapat dilakukan dengan menguatkan strategi pemberdayaan kaum perempuan melalui pelibatan stakeholder secara lebih ekstensif dan intensif. Pengintegrasian perspektif gender dengan rencana dan implementasi pembangunan dengan demikian menjadi kebutuhan tidak terhindarkan. Prinsip SDGs yang meliputi universalitas (universality), komprehensif (comprehensive), dan inklusif (no one left behind) memberikan atmosfer yang sangat kondusif bagi penguatan kesetaraan gender. SDGs juga dilengkapi dengan petunjuk pelaksanaan sehingga lebih memudahkan pemerintah bersama-sama dengan masyarakat untuk mencapai tujuan pembangunan tersebut. Tantangan pencapaian SDGs kini terletak pada kemauan (willingness) para pengambil kebijakan dan agen-agen pembangunan.
\end{abstract}

Kata Kunci: perspektif gender, pemberdayaan perempuan, dan pembangunan partisipatif 


\section{PENDAHULUAN}

Kesetaraan laki-laki dan perempuan masih menjadi perdebatan yang hangat. Meskipun kerangka regulasi sedikit banyak sudah mengalami perbaikan, tetapi kritik terhadap persoalan tersebut masih menguat. Dalam beberapa hal, perempuan memang mengalami beberapa kemajuan dan perbaikan taraf hidup. Tetapi, di dalam banyak hal lain, perempuan masih mengalami ketimpangan dan diskriminasi. Kekerasan terhadap perempuan masih marak. Catatan Komnas Perempuan menyebutkan, pada 2016 terdapat sekitar 260.000 kasus kekerasan terhadapperempuan (Suryakusuma, 2017). Perdagangan perempuan juga menjadi isu yang masih cukup menyita perhatian. Pada tahun 2016, Kemenlu memulangkan 13.714 WNI yang menjadi TKI di luar negeri dan sekitar 27.885 dipulangkan pemerintah negara asal. Dari angka tersebut, 602 di antaranya terindikasi sebagai korban perdagangan orang(Kedutaan Besar dan Konsulat AS di Indonesia, 2017). Demikian juga, praktik eksploitasi anak, termasuk anak perempuan, sebagai pekerja, termasuk di sektor prostitusi masih menjadi keprihatinan banyak pihak. Setidaknya, setiap tahun kurang lebih 150.000 anak dieksplotasi sebagai pekerja maupun sebagai pekerja seks komersial (Eddyono, Hendra, \& Budiman, 2017; Tribunnews.com, 2017). Tidak kalah mengundang perhatian adalah praktik perekrutan kaum perempuan termasuk yang di bawah umur di dalam gerakan-gerakan terorisme transnasional.

Artikel ini berargumen bahwa penekanan terhadap penguatan perspektif gender di dalam pembangunan yang dapat dilakukan melalui pemberdayaan perempuan masih sangat relevan. Relevansi itu makin jelas dengan diterbitkannya kerangka pembangunan global, yang disebut dengan Sustainable Development Goals (SDGs). SDGs menggantikan Millenium Development Goals (MDGs) yang berakhir masa berlakunya pada 2015. SDGs menjelaskan agenda keberlanjutan pembangunan pada 2030 yang terdiri dari 17 tujuan pembangunan berkelanjutan. Di dalam SDGs, kesetaraan gender (gender equality) telah disebutkan dengan eksplisit. Tujuan ke-5 dari SDGs adalah untuk mencapai kesetaraan gender dan pemberdayaan bagi semua perempuan dan para gadis pada tahun 2030, menegaskan apa yang telah digariskan pada agenda pembangunan sebelumnya, yaitu MDGs.

Meski secara eksplisit kesetaraan gender dan pemberdayaan bagi semua perempuan di semua lapisan umur telah disebutkan pada tujuan ke-5, tetapi pada dasarnya ke-17 tujuan SDGs sangat relevan bagi perbaikan kehidupan kaum perempuan. Ke-17 tujuan SDGs tersebut meliputi:

1. Pengentasan kemiskinan (no poverty)

2. Tidak ada kelaparan (zero hunger)

3. Sehat dan sejahtera (good health and well being)

4. Pendidikan berkualitas (quality education)

5. Kesetaraan gender (gender equality) 
6. Air bersih dan sanitasi(clean water and sanitation)

7. Energi bersih dan terjangkau (affordable and clean energy)

8. Pekerjaan yang layak dan pertumbuhan ekonomi

9. Industri, inovasi dan infrastruktur (industry, innovation and infrastructure)

10. Berkurangnya ketimpangan(reduces inequality)

11. Kota dan komunitas yang berkelanjutan (sustainable cities and communities)

12. Konsumsi dan produksi yang dapat dipertanggungjawabkan (responsible consumption and production)

13. Tertanganinya perubahan iklim (climate action)

14. Terpeliharanya sumber saya laut (life below water)

15. Terpeliharanya ekosistem darat (life on land)

16. Perdamaian, keadilan dan lembaga yang memadai (peace, justice and strong institution)

17. Kemitraan dalam pencapaian tujuan (partnership for the golas)

Secara regulasi, pada dasarnya sudah terdapat beberapa kemajuan di Indonesia. Pada tahun 2000, pemerintah telah mengeluarkan INPRES No. 9/2000 tentang Pengarusutamaan Gender (PUG). PUG mengharuskan pemerintah dari pusat sampai daerah mempertimbangkan kesetaraan gender baik dalam perencanaan (RPJMN, RPJMD dan RENSTRA SKPD), penganggaran (gender budget) maupun implementasi kebijakan. INPRES ini diperkuat dengan Peraturan Pemerintah No. 8/2008 tentang Tahapan, Tata Cara Penyusunan, Pengendalian dan Evaluasi Perencanaan Pembangunan Daerah pasal 33 ayat 3 yang menyebutkan secara eksplisit Perencanaan dan Penganggaran yang Responsif Gender (PPRG). PP yang mengatur tentang Penganggaran Berbasis Kinerja (PBK) ini menyebutkan PPRG sebagai salah satu indikator kinerja. Menjelang pemilu 2004, pemerintah menerbitkan Undang-undang No. 12 tahun 2003 yang menegaskan kebijakan kuota perempuan. Dengan kebijakan ini, pemerintah mengharuskan partai politik mencantumkan setidaknya 30 persen kandidat mereka dalam pemilu adalah kaum perempuan. Meski diperbaiki melalui keputusan Mahkamah Konstitusi No.22-24/PUU-VI/2008, kebijakan ini masih menjadi pertimbangan dalam penyusunan kandidasi DPR/DPRD. Pada tahun 2004 pemerintah juga telah menerbitkan Undang-undang No. 23/2004 tentang Perlindungan Korban Kekerasan Dalam Rumah Tangga. Dalam Undangundang No. 6/2014 tentang Desa, perempuan juga disebutkan secara eksplisit sebagai pihak yang layak dilibatkan dalam pengambilan keputusan di desa melalui keterwakilan di BPD dan juga turut menikmati pembangunan desa.

Sebelum diskusi tentang Undang-undang Desa marak, kita juga telah disuguhi diskusi yang hangat terkait Perda partisipasi. Meskipun tidak secara khusus ditujukan dalam rangka 
untuk memberdayakan perempuan, perda partisipasi memiliki implikasi bagi kehidupan perempuan. Pesan yang diharapkan dari lahirnya perda partisipasi di daerah semakin terbukanya kesempatan warga untuk berpartisipasi dalam decision making, sekaligus membuka akses pada informasi dan transparansi sehingga kebijakan pemerintah dapat secara nyata menyentuh kepentingan masyarakat. Kebumen dan Bantul adalah di antara sekian daerah yang memiliki peraturan mengenai partisipasi.

Sayangnya, alih-alih perda tersebut mendorong partisipasi masyarakat, beberapa kalangan dari NGOs menilai bahwa perda tersebut justru digunakan untuk memblokade akses warga terhadap proses pembuatan kebijakan. Atas nama untuk kerahasiaan negara, perda digunakan sebagai alat justifikasi membatasi keterlibatan warga dalam pembahasan anggaran, dan peraturan yang lain (Pbet_partners@yahoogroups.com.). Tentu saja ini menjadi ironi karena seharusnya ia menjadi momen untuk mendorong keterbukaan dan demokratisasi yang akan memberikan manfaat bagi berjalannya pembangunan. Perda partisipasi yang justru digunakan untuk mengatur, membatasi dan menghambat partisipasi atas nama kerahasiaan negara menunjukkan kepada kita akan lemahnya kesadaran akan pentingnya keterbukaan informasi dan kritik dalam governing processes. Lahirnya perda partisipasi yang justru membatasi akses bagi warga, secara langsung memiliki dampak kontraproduktif bagi pemberdayaan politik perempuan. Tanpa perda yang membatasi saja, perempuan sudah mengalami kesulitan untuk turut andil dalam proses pembuatan kebijakan. Lahirnya perda-perda tersebut semakin menjauhkan kesempatan bagi perempuan untuk masuk di ranah public dan menyalurkan aspirasi, apalagi mengakses dan mengontrol resources.

Beragam regulasi ini menjelaskan kepada kita bahwa ada kemajuan yang cukup signifikan yang perlu kita apreasiasi, di samping berbagai tantangan, dalam pelugasan kesetaraan gender di Indonesia secara regulatif. Tetapi, ini tidak berarti bahwa isu ketimpangan dan diskriminasi terhadap perempuan telah tuntas. Secara empiris, segenap peraturan tersebut belum cukup menyelesaikan persoalan dan ketimpangan gender. Temuan Alfirdaus, Kushandajani, \& Prabawani (2017) menyebutkan, meski porsi perhatian terhadap isu perempuan relatif meningkat, ditandai dengan makin eksplisitnya porsi anggaran dan program untuk mendukung perbaikan sosial dan ekonomi kaum perempuan, implementasi Undangundang No. 6/2014 tentang Desa yang berpihak pada kaum perempuan masih memerlukan penguatan, bahkan di desa yang dianggap maju sekalipun, perempuan masih ditempatkan sebagai pihak sekunder dalam pengambilan keputusan dan pelaksanaan pembangunan. Isu perempuan masih menjadi prioritas kedua. Oleh karena itu, memberikan penekanan kembali terhadap penguatan perspektif gender dalam pembangunan masih sangat relevan. Upaya mendorong pemberdayaan perempuan guna mendukung tercapainya SDGs, utamanya tujuan ke-5, yaitu kesetaraan gender dan pemberdayaan perempuan bagi semua umur, menjadi 
kebutuhan yang tidak terhindarkan.

\section{PERSPEKTIF GENDER, PEMBERDAYAAN PEREMPUAN DAN PEMBANGUNAN PARTISIPATIF: DISKURSUS SEKILAS}

Partisipasi seperti mantra. Begitulah kira-kira jika kita melihat pendekatan programprogram pembangunan yang diterapkan di Indonesia. Jika kita rinci, tidak satu pun program yang digulirkan, baik oleh pemerintah, lembaga donor, dan NGO, paska jatuhnya rejim Orde Baru, yang tidak mencantumkan keterlibatan warga di dalam rancangannya. Pendekatan kebalikannya, yang tidak partisipatif, sentralistik, dan top down, tidak lagi popular dan seolaholah merupakan atribut sebagai yang "jelek", "tidak demokratis", "tidak berpihak pada masyarakat". Untuk negara yang sudah lama terkooptasi oleh rejim pemerintahan otoriter, seperti Indonesia, partisipasi menjadi kata mujarab untuk meredakan dominasi sepihak pemerintah. Pendekatan partisipatif, merupakan salah satu upaya mengembalikan pendulum ekstrem terkonsentrasinya kekuasaan di tangan sedikit pengambil keputusan untuk disebarkan ke berbagai pihak yang kepentingannya terkait (MacIntyre, 2003). Terlepas dari apakah di tataran praksis pendekatan tersebut berhasil atau tidak, sebaiknya kita renungkan dahulu, pendekatan partisipatif yang seperti apa, yang memang sekiranya bisa menjawab kebutuhan substantif masyarakat.

Cornwall adalah salah seorang yang kritis terhadap konsep maupun desain partisipatif. Dalam berbagai tulisannya, ia banyak mempertanyakan relevansi pendekatan partisipatif. Bukan untuk menolaknya, tapi justru untuk menemukan format bagaimana partisipasi itu bisa benar-benar memberikan manfaat. Oleh karena itu, menurut Cornwall (2008, p. 22), setidaknya ada tiga hal yang harus dianalisis dalam pendekatan partisipatif: siapa (who), dalam hal apa (in what), dan mengapa (why). Pertama, partisipasi tidak bisa serta merta dianggap mendorong demokrasi jika justru pihak yang berkepentingan tidak terlibat di dalamnya. Ia dikooptasi oleh segelintir orang. Memang, mengharapkan partisipasi full dalam hal kehadiran dan waktu adalah naïf. Tetapi, ketika pihak-pihak yang memiliki kepentingan langsung tidak mendapat tempat untuk bergabung, pendekatan partisipatif menjadi non-sense. Seringkali, dalam pembangunan desa, misalnya, dengan dalih pendidikan warga masih terbatas, pelibatan warga hanya terbatas bagi kalangan tertentu saja. Pendekatan "siapa berpartisipasi" untuk memastikan bahwa pembangunan telah melibatkan warga -lintas ras, agama, gender, status sosial, dan suku - dan tidak terjebak dalam partisipasi elitis. Pendekatan "siapa berpartisipasi” menjadi pintu awal untuk melihat apakah partisipasi benar mendorong proses demokratisasi atau tidak.

Kedua, dalam hal apa masyarakat berpartisipasi, penting untuk melihat apakah wilayah dimana masyarakat bisa mengintervensi dan masuk di dalam program pembangunan adalah wilayah-wilayah yang inti. Mengacu pada Dryzek dalam Cornwall (2008, p. 24) menyebutkan bahwa pendekatan "dalam hal apa masyarakat berpartisipasi" memperjelas sejauh mana 
masyarakat bisa melakukan kontrol serta seberapa besar resources yang bisa diakses: apakah ranah yang dimasuki adalah ranah yang substantial atau trivial? Dalam hal perencanaan, implementasi, atau evaluasi? Dalam hal proses atau merasakan hasil? Tiap-tiap masyarakat memiliki sirkumstansis yang berbeda sehingga dalam konteks apa keterlibatannya menjadi sangat penting, adalah berbeda di antara masyarakat satu dan yang lainnya. Meminjam istilah Rose \& Shin (2001) yang menganalisis tentang demokratisasi di negara dunia ketiga tentang incomplete democracy, pendekatan "dalam hal apa masyarakat berpartisipasi”, adalah untuk memastikan agar masyarakat tidak terjebak dalam ketidak-komplitan keterlibatan.

Ketiga, pendekatan "mengapa berpartisipasi" memperjelas tujuan dari partisipasi itu sendiri. Cornwall (2008, p. 27), merujuk pada White, memeras tujuan partisipasi itu sebagaimana berikut:

\section{Tabel 1. Tipologi partisipasi White}

Bentuk Manfaat bagi partisipan Partisipasi bagi agensi Partisipasi untuk apa? yang mengimplementasikan?

$\begin{array}{lll}\begin{array}{l}\text { Nominal Legitimisasi } \\ \text { Instrumental }\end{array} & \begin{array}{l}\text { Inklusi } \\ \text { Efisiensi } \\ \text { resources yang diberikan) }\end{array} & \begin{array}{c}\text { Display } \text { (waktu, } \\ \text { mencapai efektivitas } \\ \text { biaya }\end{array} \\ \text { Representatif } & \text { Sustainabilitas } & \begin{array}{c}\text { Leverage } \\ \text { ruang bersuara }\end{array} \\ \text { Transformatif } & \text { Pemberikan }\end{array}$

Sumber: White, 'Depoliticizing development', 1996, p. 7-9.

Dengan ini, akan menjadi jelas, apakah partisipasi memang bertujuan untuk memperkuat deliberasi, dimana masyarakat memiliki ruang untuk berdialog, didengarkan, mendengarkan, mengeluarkan pikiran, berdebat, dan berdiskusi, ataukah partisipasi sekedar sebagai media stempel keputusan. Partisipasi sebagai media deliberasi juga penting untuk melihat apakah masyarakat berangkat atas kesadaran kebutuhan untuk terlibat, ataukah sekedar dimobilisasi sekelompok elit, sehingga partisipasi sekedar formalitas. Di samping itu, pendekatan "mengapa berpartisipasi", dapat digunakan untuk melacak sindrom "group think" meski untuk ini metodenya tidak mudah - dimana partisipan berpartisipasi karena dorongan kelompok mereka agar tidak dieksklusi dari kelompoknya.

Ketiga pendekatan yang disarankan Cornwall menginspirasi para aktivis gender untuk mengkritisi pendekatan partisipatif yang banyak ditekankan agen-agen pembangunan (donor, pemerintah, NGOs). Perempuan, karena identitas biologisnya, seringkali dilalaikan sebagai pihak yang juga memiliki kepentingan dalam program pembangunan dan pengambilan 
keputusan. Dan pendekatan "siapa berpartisipasi” menjadi pertanyaan penting pertama. Kalaupun dilibatkan, pelibatannya seringkali terjebak dalam apa yang oleh Bacchi (2006) disebut sebagai "the politics of presence", dimana kehadiran perempuan sudah dianggap cukup, terlepas apakah kita sudah memberikan ruang berdeliberasi maupun akses terhadap resources atau belum. Dengan ini, pendekatan "dalam hal apa berpartisipasi" juga penting untuk melihat di ranah mana perempuan terlibat. Untuk itu, mengawal pembangunan dengan pendekatan partisipatif penting untuk memastikan bahwa program yang dilaksanakan benar-benar memberikan implikasi bagi perempuan dan relasi gender yang setara sehingga pendekatan "mengapa" berpartisipasi pun memerlukan titik tekan yang sama dengan pendekatan "siapa berpartisipasi" dan "dalam hal apa berpartisipasi".

Dalam pembangunan infrastruktur, misalnya, kita mungkin tidak menyadari bahwa akan ada implikasi positif dan negatif dari program yang kita jalankan yang secara spesifik mempengaruhi kehidupan perempuan laki-laki secara berbeda. Kita mungkin tidak menyadari bahwa penyediaan air bersih akan sangat membantu ibu rumah tangga untuk keperluan dapur mereka. Pembangunan jembatan dan jalan juga secara langsung dapat mempengaruhi aktivitas para remaja putri untuk bersekolah, dan sebagainya. Dengan mempertimbangkan perspektif gender atas program pembangunan kita, baik dalam hal perencanaan, implementasi dan evaluasi, maka kemungkinan bahwa program kita akan memberikan manfaat yang lebih besar kepada masyarakat pun akan terbuka semakin lebar. Dan mempertajam perspektif gender bukan hanya berarti melibatkan sebanyak mungkin perempuan, tetapi juga mempertajam sensitivitas kita terhadap kebutuhan mereka dalam program pembangunan yang kita rencanakan.

Bahkan untuk program yang secara sengaja ditujukan bagi perempuan, penajaman perspektif gender tetap diperlukan. Dalam program safety net, misalnya, di satu sisi donor bermaksud membantu mengurangi beban perempuan yang umumnya berperan sebagai ibu rumah tangga. Perempuan menjadi target utama program, dengan maksud agar mereka memperoleh akses sandang dan pangan, karena selama ini, di dalam keluarga dan komunitas mereka cenderung dinomorduakan setelah laki-laki dan anggota keluarga lainnya. Dalam program mikrokredit, misalnya, di satu sisi program dirancang untuk memberikan akses kapital kepada perempuan supaya mereka bisa menjalankan peran produktif mereka. Akan tetapi, ketika perspektif gender itu sendiri tidak memperoleh proporsi yang memadai untuk dipertimbangkan dalam hal perencanaan dan desain, program-program yang awalnya ditujukan secara spesifik bagi perempuan, justru bisa menjadi kontraproduktif (pengalaman program mikrokredit di Bangladesh justru meningkatkan jumlah kekerasan dalam rumah tangga). Penyebabnya mungkin simple: karena kita tidak pernah tahu - atau mungkin tidak aware - siapa yang memiliki otoritas untuk mengambil keputusan, termasuk otoritas untuk 
memiliki, mengatur dan membagi resources di dalam rumah tangga. Dalam program safety net, misalnya, seringkali perempuan mengalah dan mendahulukan suami dan anak-anak mereka, meski jelas merekalah target dari program tersebut. Dalam program mikrokredit, misalnya, kita tidak pernah tahu, sampai rumah, siapa sebenarnya yang mengambil alih kapasitas untuk mengatur keuangan dan menikmati hasilnya. Oleh karena setiap kebijakan, program pembangunan dan penyediaan layanan public memiliki implikasi yang berbeda bagi laki-laki dan perempuan, sekedar menekankan partisipasi belum cukup. Program juga mesti sensitif terhadap pola relasi gender yang melingkupi konteks dimana kita melaksanakan sebuah program, karena ia secara langsung dan tidak langsung mempengaruhi cara perempuan dan laki-laki bertindak dan mengambil keputusan.

\section{PERKEMBANGAN PERSPEKTIF GENDER DAN PEMBANGUNAN}

Kesadaran bahwa kaum perempuan tertinggal dalam pembangunan melahirkan berbagai tawaran pendekatan. WID dan GAD adalah beberapa di antara yang banyak diadopsi lembaga- lembaga donor dan pemerintah. Kedua pendekatan ini banyak mempengaruhi kebijakan pembangunan seperti MDGs (Millennium Development Goals) yang dicetuskan oleh UNDP, dan kemudian diperbarui melalui Sustainable Development Goals (SDGs) pada September 2015, banyak diadopsi lembaga donor juga pemerintah nasional. Namun, kritik tentang tidak lengkapnya pengintegrasian perspektif gender, baik di dalam rumusan kebijakan program-program tersebut, maupun desain program kebijakannya, tetap tidak terhindarkan. Berikut sekilas tentang WID, GAD, MDGs, dan SDGs.

\section{WID dan GAD}

Upaya-upaya untuk mengatasi kesenjangan partisipasi antara laki-laki dan perempuan sebenarnya sudah banyak dilakukan. Yang paling dominan adalah WID (Women in Development) dan GAD (Gender and Development). WID adalah untuk mendorong produktivitas perempuan dalam pembangunan ekonomi (Razavi \& Miller, 1995, pp. 2-6). Advokat WID melihat sumber masalah kesenjangan laki-laki dan perempuan adalah ketika pekerjaanpekerjaan rumah tangga yang dilakukan perempuan tidak pernah dihargai karena alasan tidak memiliki nilai ekonomis. Pembagian ranah domestic dan public merugikan perempuan karena menyebabkan perempuan menderita ketertinggalan akses informasi, pengetahuan dan kemampuan berproduksi. WID adalah untuk mengatasi masalah kesenjangan tersebut, sehingga pendekatan-pendekatannya lebih banyak bersifat training, peningkatan skill, pendidikan formal, dan sebagainya.

Sementara itu, GAD adalah untuk mempertajam sense bahwa eksklusi tidak hanya terjadi karena perempuan memiliki identitas biologis yang bersifat feminin, tetapi bahwa relasi 
sosial yang dikonstruksi oleh institusi dan sistem sosial yang mendeskripsikan bagaimana lakilaki dan perempuan seharusnya bertindak dan bertanggungjawab, memiliki pengaruh terhadap akses/kontrol pengambilan keputusan dan resources (Razavi \& Miller, 1995, pp.12-17). GAD menganalisis relasi gender dan implikasinya pada laki-laki dan perempuan secara lebih kompleks karena berusaha melihat irisannya dengan masalah status sosial, ras, kelas dan struktur sosial. Kedua pendekatan ini banyak diadopsi lembaga-lembaga donor, NGO maupun pemerintah untuk memberdayakan kamu perempuan. World Bank dan UNDP adalah di antara lembaga internasional yang gencar mengkampanyekan keterlibatan perempuan dalam program- programnya. Akan tetapi, sejauhmana pendekatan yang mereka tekankan memiliki implikasi yang maksimal bagi pemberdayaan perempuan tentu memerlukan analisis kritis. Berikut adalah beberapa kebijakan dan program yang dimaksudkan untuk meningkatkan taraf hidup perempuan.

\section{MDGs (UNDP)}

Dalam misinya mengentaskan kemiskinan, the United Nation and Development Program (UNDP) menelurkan kebijakan yang disebut Millennium Development Goals (MDGs), terdiri dari delapan butir tujuan pembangunan. Dua diantara delapan butir tersebut secara langsung berkaitan dengan perempuan dan pemberdayaan perempuan, yaitu butir 2 dan 3. Masingmasing berisi tentang pendidikan dasar universal (butir 2), promosi kesetaraan gender dan pemberdayaan perempuan (butir 3), dan peningkatan kesehatan ibu (butir 5). Target ketiga dari butir 2 MDG menyatakan bahwa menjelang tahun 2015, perlu memastikan bahwa anakanak dimanapun berada, laki-laki dan perempuan sama, mampu menyelesaikan pendidikan dasar mereka. Indikator pencapaian target ini adalah jumlah siswa terdaftar di sekolah dasar, proporsi siswa di kelas, dan tingkat melek huruf penduduk berusia 15-24 tahun. Sementara itu, target ketiga butir kegia MDG menyatakan perlunya menghapus kesenjangan gender di sekolah dasar dan sekolah menengah, pada tahun 2005, dan di semua level pendidikan sebelum tahun 2015. Indicator pencapaiannya adalah perbandingan perempuan dan laki-laki di sekolah dasar, menengah, dan pendidikan tinggi, perbandingan tingkat melek huruf perempuan dan laki-laki usia 15-24 tahun, kesetaraan gaji pekerja di sector pertanian, dan proporsi kursi perempuan di lembaga perwakilan rakyat di tingkat nasional.

Secara sekilas, butir-butir MDGs memang seolah-olah telah memberikan tekanan pada perspektif gender. Penekanan pada kesetaraan laki-laki dan perempuan dalam mengakses pendidikan dan lembaga perwakilan seolah-olah mencerminkan kebijakan UNDP sudah melek gender. Akan tetapi, jika kitamelihat lebih jauh, indikator yang digunakan MDG sangat bersifat kuantitatif, masih berkutat pada angka dan belum memberikan tekanan yang berarti pada kualitas dan akses perempuan terhadap resources dan pengambilan keputusan. Oleh karena 
itu, sebagaimana ditekankan Kabeer (2005, p. 17), kita mesti melihat secara kritis lembaga pendidikan seperti apa yang akan kita tawarkan bagi pemberdayaan perempuan. Bagaimana dengan guru yang mengajar, kurikulum juga metode pembelajaran, karena di sisi yang lain, lembaga pendidikan justru menjadi media yang paling efektif untuk mereproduksi ketidakadilan sosial. Tidak juga kita bisa menjamin bahwa menggaji perempuan di sektor pertanian akan benar- benar memberdayakan perempuan, karena bisa saja justru menjadi eksploitatif karena struktur kerja yang tidak adil. Demikian juga, meski diakui bahwa representasi perempuan di lembaga perwakilan amatlah penting, akan tetapi kita mesti kritis melihat siapa mewakili siapa. Karena, di nagara berkembang seperti India dan Indonesia, kaum miskin perempuan jarang sekali mendapat kesempatan untuk memiliki wakil di parlemen (Kabeer, 2005, p. 22).

\section{SDGs (Sustainable Development Goals)}

Sangat disadri bahwa pencapaian MDGs masih belum optimal. Meski ada kemajuan, masih ada persoalan mendasar termasuk yang terkait dengan kesetaraan gender. Pandey Pandey (2017) menyebutkan selama 15 tahun terakhir ini secara umum telah terdapat perbaikan- perbaikan dalam kaitannya dengan kehidupan dan kesejahteraan perempuan. Angka Kematian Ibu (AKI) cenderung menurun. Hingga tahun 2013 penurunan tersbeut tercatat sampai 45 persen. Angka harapan hidup perempuan relatif lebih tinggi dibandingkan dengan kaum laki-laki di seluruh wilayah di dunia. Jumlah anak perempuan yang masuk sekolah juga terus meningkat dari 80 persen pada tahun 1990 menjadi 91 persen pada tahun 2015. Jumlah perempuan yang duduk di lembaga legislatif maupun tampuk kepemimpinan dalam pemerintahan dan berbagai organisasi juga mengalami kenaikan. Terakhir, jumlah perempuan yang tercatat dalam lapangan kerja yang dibayar juga terus bertambah. Sampai tahun 2015, setidaknya 41 persen lapangan kerja berbayar diisi oleh pekerja perempuan. Pada tahun 1990 jumlah itu masih sekitar 35 persen.

Tetapi, tantangan perbaikan taraf hidup masih menantang di depan. Pandey (2017) mengidentifikasi 5 area yang krusial. Area tersebut adalah Angka Kematian Ibu dan akses kesehatan yang timpang; kekerasan oleh pasangan (Intimate Partner Violence-IPV) dan kekerasan berdasar gender (gender based violence); pernikahan anak- anak (child marriage); ketidakseimbangan demografis antara laki-laki dan perempuan (demographic imbalance around gender); kurangnya kebijakan yang mampu merespon perubahan struktur keluarga, misalnya yang disebabkan oleh peningkatan perceraian, migrasi, relokasi, maupun urbanisasi. Area ini sangat berpengaruh terhadap hajat hidup perempuan dan isu kesetaraan gender. SDGs memberikan harapan baru karena mencakup area pemberdayaan perempuan yang lebih luas. Secara eksplisit tujuan ke-5 SDGs menyebutkan kesetaraan gender dan pemberdayaan untuk 
kaum perempuan dan para gadis. Indikator yang disebutkan pada tujuan ke-5 SDGs antara lain penghapusan diskriminasi perempuan, penghapusan pernikahan anak-anak, kesempatan yang sama bagi semua perempuan terhadap semua level pengambilan keputusan, akses universal untuk kesehatan seksual dan reproduksi, juga penggunaan teknologi untuk perluasan pemberdayaan perempuan (Kementerian Perencanaan Pembangunan Nasional Republik Indonesia/Badan Perencanaan Pembangunan Nasional, 2017, p. 43). Pada level kebijakan, respon yang makin baik dari pemerintah juga memberikan optimisme pencapaian SDGs bagi kesetaraan gender. Seperangkat peraturan dan implementasi kebijakan juga telah menunjukkan perbaikan taraf hidup kaum perempuan serta peningkatan akses dan sumberdaya dalam berbagai ranah kehidupan, sebagaimana dipaparkan di atas.

Namun demikian, SDGs belum mengantisipasi kompleksitas politik yang sangat mungkin menghambat pencapaian tujuan kesetaraan gender tersebut. Maraknya korupsi di negara berkembang termasuk Indonesia yang secara langsung maupun tidak langsung mempengaruhi akses dan kontrol kaum perempuan atas sumberdaya, utamanya mereka yang berasal dari kalangan menengah ke bawah, belum benar-benar diperhitungakn sebagai hambatan dalam pencapaian tujuan kesetaraan gender dan pemberdayaan perempuan. Demikian juga dengan struktur politik yang cenderung oligarkis. Struktur politik oligarkis menghambat kesempatan perempuan untuk turut serta berperan aktif dalam pengambilan keputusan. Struktur oligarkis ini tidak jarang juga mengendalikan kursi kekuasaan yang dipegang kaum perempuan, menghasilkan kepemimpinan perempuan yang alih-alih memberdayakan kaum perempuan, tetapi sebaliknya justru melayani para pemegang kendali ologarki. Kompleksitas politik ini patut menjadi pertimbangan para pengambil keputusan dalam mendesain kebijakan yang dapat mendukung pencapaian SDGs.

\section{PENAJAMAN PERSPEKTIF GENDER DAN PEMBER- DAYAAN PEREMPUAN DALAM PENCAPAIAN SDGS}

Dari sekilas argumentasi yang dipaparkan di atas, menjadi jelas bahwa mengintegrasikan perspektif gender dalam pembangunan bukan hal yang mudah. Berbagai persoalan, dari hambatan birokratis, kurang detilnya penjabaran indikator kebijakan dan program berperspektif gender, masih terjebaknya pengukuran pemberdayaan perempuan dalam indikator kuantitatif (angka) bukan kualitatif, sampai kompleksnya struktur politik yang melingkupi kebijakan di suatu pemerintahan sangat berpengaruh terhadap keberhasilan pembangunan, termasuk yang terjabarkan dalam SDGs.

Tetapi, beberapa hal patut kita pertimbangkan. Pertama, bahwa upaya pengintegrasian perspektif gender tetap merupakan kebutuhan yang tidak terhindarkan. Kedua, intervensi kebijakan dalam bentuk penjabaran detil prosedur dan detil operasional kebijakan secara jelas 
menjadi penting. Ia dapat berpengaruh pada bagaimana sebuah kebijakan, program, dan rancangan pembangunan dapat memiliki implikasi positif bagi perempuan dan kesetaraan gender. Kaitannya dengan pencapaian tujuan ke-5 SDGs, pendapat Moser, Longwe dan Cornwal masih sangat relevan dan patut dipertimbangun. Ketiga akademisi ini berusaha membangun sebuah pendekatan yang sekiranya dapat membantu kita mengintegrasikan kebutuhan spesifik perempuan dalam rancangan pembangunan yang kita susun. Tanpa bermaksud melupakan fakta bahwa keragaman konteks tetaplah patut dipertimbangkan, pendekatan ketiga ahli terbut kiranya cukup penting untuk dicermati.

Kerangka analisis yang ditawarkan Moser (1993) untuk mempertajam perspektif gender dalam pembangunan adalah dengan membedakan kebutuhan praktis dan strategis perempuan. Kebutuhan praktis adalah kebutuhan sehari-hari perempuan seperti kesehatan, sandang, pangan, dan papan, yang sifatnya immediate. Pengidentifikasian kebutuhan praktis tidak secara khusus ditujukan untuk mendekonstruksi pembagian kerja berdasarkan gender, sehingga ia tidak secara khusus berkaitan dengan pendekonstruksian hubungan kekuasaan (power relations). Sementara itu, kebutuhan strategis gender berkaitan dengan pemberdayaan dan penumbuhan kesadaran pentingnya posisi setara laki-laki dan perempuan. Pendidikan politik dan pendidikan sadar gender gender termasuk di sini. Mengidentifikasi kebutuhan strategis perempuan penting untuk membangun kesadaran bahwa perempuan setara dengan laki-laki. Ia juga penting untuk memperluas akses perempuan terhadap resources dan pengambilan keputusan.

Dalam hal mendesain rencana pembangunan, pendekatan yang ditawarkan Moser bermanfaat untuk mengidentifikasi daftar kegiatan yang kita miliki dengan implikasi yang bakal muncul bagi penguatan kesetaraan gender. Membangun jalan sehingga ia memudahkan kaum perempuan untuk mengakses pasar, sekolah dan puskesmas adalah bagian identifikasi kebutuhan praktis gender. Demikian juga dengan memudahkan akses air minum bagi perempuan di daerah kering. Sementara itu, melibatkan perempuan dalam komite sekolah, komite perencanaan pembangunan desa, pelatihan kesetaraan gender bagi kaum laki-laki, adalah beberapa contoh klasifikasi kebutuhan strategis gender. Kedua klasifikasi kebutuhan sama-sama penting. Kebutuhan praktis membantu perempuan untuk survive, sedangkan kebutuhan strategis membantu membangun gender equality. Pendekatan Moser dibangun atas kesadaran bahwa perempuan dan laki-laki memiliki cara yang berbeda untuk berpartisipasi dalam pembangunan. Oleh karena itu, gender needs assessment pun menjadi penting untuk mengidentifikasi kebutuhan apa yang perlu ditekankan ketika kita melakukan intervensi dalam pembangunan.

Pendekatan yang tidak jauh berbeda ditawarkan oleh Longwe (1991). Ia membedakan women's concerns dari women's issues bagi program pemberdayaan perempuan. Women's 
concerns adalah hal-hal yang berkaitan dengan pembagian kerja dan tanggungjawab berdasarkan gender, seperti pembagian ranah publik dan ranah domestik, sementara women's issues adalah ketika pembagian kerja dan tanggungjawab tersebut menciptakan ketimpangan, diskriminasi, dan ketidakadilan. Disamping itu, Longwe menekankan pentingnya conscientization, dimana para perancang pembangunan perlu mengidentifikasi perbedaan kebutuhan laki-laki dan perempuan, bagaimana program yang kita tawarkan akan direspon secara berbeda oleh laki-laki dan perempuan, juga bagaimana ia memiliki implikasi secara berbeda bagi laki-laki dan perempuan. Jika kita melihat pendekatan yang ditawarkan Longwe, conscientization menjadi penting karena ia menjembatani kebutuhan praktis dengan kebutuhan strategis sebagaimana yang ditekankan oleh Moser. Dalam istilah yang berbeda, Longwe menyebut kebutuhan praktis sebagai "welfare" dan "access", lalu menyebut kebutuhan strategis sebagai "participation" dan "control". Longwe merangking kebutuhan tersebut dan meletakkan conscientization di tengah-tengah sebagaimana berikut:

Tabel 2. Lima 'level' pembangunan Longwe

\begin{tabular}{|l|}
\hline Control \\
\hline Participation \\
\hline Access \\
\hline Welfare
\end{tabular}

Level ini bersifat hirarkis, dimana welfare ada di urutan paling bawah, diikuti access, conscientization, participation dan control. Di level paling bawah, Longwe meletakkan welfare, yang mencakup kebutuhan pangan, pendapatan dan kesehatan. Access mencakup pendidikan, pelatihan, akses terhadap economic resources (tanah dan modal), lapangan kerja, pengambilan keputusan dalam keluarga, dan sebagainya. Bagi Longwe, access berbeda dengan welfare karena di titik inilah perbedaan kesempatan dan kemampuan laki-laki dan perempuan untuk memperolehnya mulai terasa berbeda. Konstruksi sosial dan hubungan kekuasaan sudah terasa pengaruhnya di sini. Conscientization merupakan level berikutnya dimana apresiasi atas perbedaan peran dan tanggung jawab antara laki-laki dan perempuan diperlukan. Dari pengidentifikasian perbedaan ini, kebutuhan spesifik dapat diidentisikasi dan secara pelanpelan ketimpangan gender dapat diubah. Sebagai lanjutan dari conscientization tersebut, diperlukan adanya keterlibatan perempuan dalam pembangunan, yang oleh Longwe dimasukkan dalam level participation. Di sini perempuan masuk dalam decision making dan perencanaan supaya berbagai kebijakan dan program pembangunan sensitive terhadap kebutuhan mereka. Akhirnya, ketika kesempatan untuk berpartisipasi diperoleh perempuan secara sama dengan laki-laki, perempuan perlu memiliki kesempatan yang sama untuk 
mengontrol resources dan merasakan manfaat dari resources tersebut. Bagi Longwe, control adalah level dimana kesetaraan gender itu dapat terwujud.

Meski pendekatan yang ditawarkan Longwe sedikit lebih rumit jika dibandingkan dengan Moser, tetapi, ia membantu kita mengidentifikasi lebih detil kebutuhan kaum perempuan, termasuk langkah-langkah apa yang kita perlukan supaya program pembangunan yang kita rancang dapat memperkuat kesetaraan gender. Meskipun Longwe banyak dikritik karena ia seolah-olah menyederhanakan hirarki kebutuhan perempuan dan dianggap mengelak dari kerumitan konteks dimana perempuan memiliki ukuran yang berbeda terhadap kebutuhan mereka, pendekatan yang ditawarkan Longwe dapat menjadi rujukan bagi kita yang concerned dengan program pemberdayaan perempuan.

Sementara itu, pendekatan yang ditawarkan Cornwall $(2000,2003,2008)$ dapat digunakan untuk melengkapi pendekatan yang ditawarkan Moser dan Longwe. Cornwall (2000, p. 7) menggarisbawahi adanya kebutuhan untuk mengidentifikasi kompleksitas dan keberagaman pengalaman masyarakat lokal. Garisbawah ini signifikan karena perspektif tunggal para ahli dan konsultan pembangunan tidak dapat digunakan secara merata bagi masyarakat setiap konteks masyarakat. Ia mungkin kompatibel, tapi hanya di sebagian aspek saja. Dari sini, esensi partisipasi itu sendiri menjadi jelas. Partisipasi memungkinkan masyarakat mengekspresikan pengalaman, kebutuhan dan pendapat mereka masing-masing. Dan untuk ini yang diperlukan adalah ruang, atau yang dalam istilah Cornwall disebut dengan space (Cornwall, 2003). Klaim untuk menolak pendapat Cornwall mungkin saja muncul dengan alasan tidak semua masyarakat mampu memanfaatkan space, dan dari sini elite capture seolaholah mendapatkan pembenaran. Tetapi, justru dari sinilah kebutuhan untuk mengerti bahasa masyarakat menyampaikan pendapat dan kebutuhan mereka, dengan cara mereka sendiri, menjadi amat penting. Masyarakat bukan tidak mengerti cara menggunakan space, juga bukannya tidak paham akan pentingnya space. Masyarakat hanya butuh space itu ada/disediakan. Namun demikian, Cornwall bukanlah tipe advokat gender yang utopis. Conrwall menyadari bahwa full participation adalah sesuatu yang sulit, atau bahkan tidak mungkin, mengingat constrains partisipasi bisa datang dari aktivitas harian masyarakat yang tidak bisa ditinggalkan (bertani, memasak, berdagang, belanja, dan sebagainya). Oleh karena itu, Cornwall juga menekankan pentingnya representasi. Terkait dengan ini, representasi seperti apa yang akan dibangun tentu menjadi penting, dan sehingga pendekatan partisipasi "siapa", "dalam hal apa", dan "mengapa" sebagaimana yang ditekankan di bagian awal tulisan ini menjadi krusial.

Di sisi lain, Cornwall (2000, p. 14) menyadari bahwa memobolisasi perempuan dalam ranah decision making yang tidak biasa mereka masuki dapat menimbulkan pertanyaan tentang apakah program pemberdayaan yang kita bawa cukup mengakar. Alih-alih memberdayakan, 
jangan-jangan pendekatan semacam ini akan ditolak, bahkan oleh perempuan sendiri. Dalam hal ini, ruang adaptasi sebelum pendekatan gender-sensitive diterapkan menjadi jelas diperlukan. Salah satu cara adaptasi yang ditawarkan Cornwall (2000, p. 15) adalah pertamatama dengan memisahkan ruang berdiskusi antar laki-laki dan perempuan. Lalu, biarkan perempuan berdeliberasi sampai mereka menemukan makna pentingnya lalu menyadari bahwa keterlibatan bersama ternyata penting dan memberikan manfaat Cornwall (2000, p.16) Dari sini, masyarakat akan mengerti arti inklusi, mutual learning, dan active engagement. Maksud Cornwall (2000, p. 28) menekankan adaptasi sebelum melakukan transformasi perspektif gender dalam perencanaan pembangunan adalah untuk mengingatkan kita bahwa kondisi masyarakat itu beragam. Gender-sensitive program yang kita bawa jangan sampai justru melalaikan kita pada dinamika sosial yang membentuk keberagaman masyarakat sehingga warna dan pola relasi gender yang mengkerangkai struktur sosial di masyarakat pun beragam.

Dengan ini, Cornwall menegaskan bahwa pendekatan gender sensitive mesti sensitif terhadap konteks dan pola hubungan kekuasaan dalam masyarakat. Dan pemberdayaan perempuan adalah tentang menggeser struktur kekuasaan sehingga ia lebih setara bagi laki dan perempuan (Cornwall, 2008, p. 73). Cornwall melengkapi kontribusi yang diberikan Moser dan Longwe dalam pemberdayaan perempuan dengan mengingatkan pentingnya mengenali keberagaman dinamika sosial dan lokalitas.

Dengan menerapkan pembedaan strategic dan practical need, conscientization dan penyusunan gender sensitive program, sebagaimana dijelaskan di atas, upaya peningkatan kesetaraan gender dan pemberdayaan perempuan bagi semua umur sebagaimana yang ditekankan dalam tujuan ke-5 SDGs, menjadi lebihjelas roadmap-nya. Pembedaan strategic dan practical need adalah langkah dasar, sementara conscientization adalah langkah lanjutan dalam penguatan kesadaran politis baik laki-laki dan perempuan atas pentingnya kesetaraan antara laki-laki dan perempuan. Sementara itu, gender sensitive program dapat menjadi basis petunjuk pelaksanaan kebijakan pembangunan yang berperspektif gender. Ketiga pendekatan di atas, dengan demikian, memudahkan kita mengintegrasikan penajaman perspektif gender dan pemberdayaan perempuan di dalam desain pembangunan.

\section{KESIMPULAN}

Kita tidak bisa menafikan bahwa setiap kebijakan, intervensi, program pembangunan dan pelayanan publik memiliki implikasi gender. Ia akan diterima dan dipahami secara berbeda oleh laki-laki dan perempuan, dan ia akan memiliki dampak yang berbeda bagi kehidupan lakilaki dan perempuan. Oleh karena itu, naïf ketika berbagai kebijakan dan program tidak disertai dengan perspektif gender.

Meski telah mengalami perbaikan, kesetaraan gender perlu mendapatkan penekanan 
yang lebih besar mengingat persoalan diskriminasi dan ketimpangan yang masih dihadapi kaum perempuan. Dengan merujuk pada tujuan ke-5 SDGs, kesetaraan gender dan pemberdayaan perempuan bagi semua umur dapat lebih lugas lagi dipromosikan dalam kebijakan dan pembangunan.

Di sisi lain, dalam hal pembangunan, respon yang diberikan terhadap kenyataan berbedanya laki-laki dan perempuan, bahkan antara sesama laki-laki dan perempuan sendiri, amat beragam. Beberapa lembaga internasional telah mencoba mengintegrasikan perspektif gender. Beberapa institusi politik yang lain masih menolak secara eksplisit menyertakan perspektif gender.

Mengingat pentingnya integrasi perspektif gender dihadapkan pada masih lemahnya pengintegrasian itu dalam berbagai program dan kegiatan, tidak dapat dihindari lagi, penajaman perspektif gender menjadi mendesak. Kerangka yang ditawarkan Moser dan Longwe sangat membantu untuk mengidentifikasi relasi gender dan dampaknya bagi laki-laki dan perempuan, serta bagaimana kita mendesain program dan kebijakan yang responsif terhadap kebutuhan spesifik laki-laki dan perempuan.

Di sisi lain, Cornwall telah sangat membantu dengan mengingatkan pentingnya mengidentifikasi dinamika sosial, supaya pemberdayaan perempuan dapat sesuai dengan konteks. Cornwall mempertajam sense yang ditegaskan Moser dan Longwe. Misi dari pengintegrasian ketiga pendekatan mereka adalah pembangunan mesti didesain dengan mengenali kebutuhan spesifik perempuan dan laki- laki, dengan tetap aware bahwa definisi penjabaran tentang 'kebutuhan' itu sendiri sangat beragam, karena relasi gender dan pola hubungan kekuasan berbeda di satu konteks dengan konteks yang lainnya.

\section{DAFTAR PUSTAKA}

Alfirdaus, L. K., Kushandajani, \& Prabawani, B. (2017). Gender and Village Governance Transformation in Indonesia: An Initial Assessment (2017 Working Paper Series No. 2). Yogyakarta. Retrieved from http://iif.or.id/wp-content/uploads/2017/10/02- AlfirdausLaila-Kholid-Gender-and-Village-Governance-Transformation.pdf

Bacchi, C. (2006). Arguing for and against quotas : theoretical issues. In Women, quotas and politics (1st ed., p. 312). Hoboken: Routledge.

Cornwall, A. (2000). Making a difference? : gender and participatory development. Brighton: Institute of Development Studies, University of Sussex.

Cornwall, A. (2003). Whose voices? Whose choices? Reflections on gender and participatory development. World Development, 31(8), 1325-1342. https://doi.org/10.1016/S0305750X(03)00086-X

Cornwall, A. (2008). Democratising engagement: what the UK can learn from international experience. London: Demos. Retrieved from 
https://assets.publishing.service.gov.uk/media/57a08bc0e5274a2

7b2000d29/Democratising_Engagement-Cornwall.pdf

Eddyono, S. W., Hendra, R., \& Budiman, A. A. (2017). Melawan praktik prostitusi anak di Indonesia dan tantangannya. Jakarta: Institute for Criminal Justice Reform. Retrieved from http://icjr.or.id

Kabeer, N. (2005). Gender equality and women's empowerment: a critical analysis of the third Millennium Development Goal. Gender and Development, 13(1), 13-24.

Kedutaan Besar dan Konsulat AS di Indonesia. (2017). Laporan Tahunan Perdagangan Orang 2017. Retrieved December 3, 2017, from https://id.usembassy.gov/id/laporan-tahunanperdagangan- orang-2017/

Kementerian Perencanaan Pembangunan Nasional Republik Indonesia/Badan Perencanaan Pembangunan Nasional. (2017). Voluntary National Review (VNR): Eradicating poverty and promoting prosperity in a changing world. Jakarta. Retrieved from https://sustainabledevelopment.un.org/content/documents/15705I ndonesia.pdf

Longwe, S. H. (1991). Gender awareness: the missing element in the Third World development project. In T. Wallace \& C. March (Eds.), Changing perceptions: writings on gender and development (p. 324). Oxford: Oxfam.

MacIntyre, A. J. (2003). The power of institutions: political architecture and governance. Ithaca ;;London: Cornell University Press.

Moser, C. O. N. (1993). Gender planning and development: theory, practice, and training. Routledge.

Pandey, S. (2017). The Road From Millennium Development Goals to Sustainable Development Goals by 2030. Affilia, 32(2), 125-132. https://doi.org/10.1177/0886109917704040 Pbet_partners@yahoogroups.com. pbet_partners@yahoogroups.com. (n.d.). pbet_partners. Retrieved from pbet_partners@yahoogroups.com

Razavi, S., \& Miller, C. (1995). From WID to GAD: Conceptual Shifts in the Women and Development Discourse. Geneva. Retrieved from https://www.econstor.eu/bitstream/10419/148819/1/863101828.p df

Rose, R., \& Shin, D. C. (2001). Democratization Backwards: The Problem of Third-Wave Democracies. British Journal of Political Science. Cambridge University Press. https://doi.org/10.2307/3593267

Suryakusuma, J. (2017). Darurat Kekerasan terhadap perempuan di Indonesia. Retrieved December 13, 2017, from https://www.dw.com/id/darurat-kekerasanterhadap-perempuan- di-indonesia/a-41422351

Tribunnews.com. (2017, October 12). Pemerintah diminta serius tangani kasus prostitusi Anak dan Pornografi. Tribunnews.Com. Retrieved from http://www.tribunnews.com/nasional/2017/10/12/pemerintah- diminta-serius-tanganikasus-prostitusi-anak-dan-pornografi 